\title{
Influence of kitchen structures on household exposure to firewood-induced volatile organic compounds in Senwabarwana villages
}

\author{
Khomotso Semenya $^{1}$ (D) Fannie Machete ${ }^{1}$
}

Received: 22 March 2019 / Accepted: 7 July 2020 / Published online: 16 July 2020

(C) The Author(s) 2020

\begin{abstract}
This paper presents the extent to which kitchen structures influence household exposure to firewood-induced volatile organic compounds (VOCs). The sample consisted of 69 firewood users who were conveniently sampled from Senwabarwana Villages. An Integrated Environmental Health Risk Assessment framework (IEHRA) was adopted as the research methods of the current study. The VOC samples were collected from selected priority firewood species used in the study area, namely mushu (Umbrella thorn), mohwelere (red bushwillow), moretshe (Sickle bush), motswiri (Leadwood) and mokgwa (Black monkey thorn). Four VOCs, namely benzene, toluene, ethylbenzene and xylene were analysed from each of the selected plant species. Available literature shows that these VOCs are associated with the kind of common firewood used in the study area. The outcomes of this study reveal that mushu emits the highest concentration of the four selected VOCs, followed by moretshe, mohwelere, mokgwa and motswiri, respectively. The influence of kitchen structural factors such as number and positioning of windows, fireplace or stove type, roofing material and designs, among others on the concentration and indoor dispersion of VOCs was also investigated. Behavioural practices of households during fire making such as opening or closing of doors and windows during cooking, water heating and space heating were also found to influence exposure levels. Consequently, low VOCs emitting firewood species and kitchen structural designs have been confirmed as the key drivers of firewood-induced VOC exposure.
\end{abstract}

Keywords Integrated Environmental Health Risk Assessment framework · Firewood emissions $\cdot$ Ill health $\cdot$ Kitchen structures, volatile organic pollutants

\section{Introduction}

The combustion of firewood for cooking in poorly ventilated kitchens with open fire is of a great concern because it exposes occupants to indoor air pollutants. Firewood smoke contains a complex mixture of pollutants such as particulate matter, inorganic gases (e.g. carbon monoxide, nitrogen oxides, and sulphur dioxides), polycyclic aromatic hydrocarbons (PAHs) and volatile organic compounds (VOCs), which have the potential to harm the environment and human health (Nielsen et al. 2008;

Electronic supplementary material The online version of this article (https://doi.org/10.1007/s11869-020-00872-0) contains supplementary material, which is available to authorized users.

Khomotso Semenya

semenk@unisa.ac.za

1 College of Agriculture and Environmental Sciences, University of South Africa, Science Campus, Florida Park, Roodepoort, Republic of South Africa
Williams et al. 2012). Many studies have been conducted on the monitoring of both individual gaseous pollutant (e.g. carbon monoxide, nitrogen oxides and sulphur dioxides) and particulate air pollutant (Kapwata et al. 2018; Olave et al. 2017; Mitchell et al. 2016; Parajuli et al. 2016; Joon et al. 2014). Monitoring of volatile organic compounds (VOCs) in kitchens where firewood is used for cooking has received little attention in the scientific literature.

Volatile organic compounds are chemicals that contain carbon, hydrogen and oxygen and are gases at room temperature (Nielsen et al. 2008). According to USEPA (2018), volatile organic compounds "are organic chemical compounds whose composition makes it possible for them to evaporate under normal indoor atmospheric conditions and pressure these excludes carbon monoxide, carbon dioxide, carbonic acid, metallic carbides and ammonium carbonate". Volatile organic compounds are derived from benzene, toluene, ethylbenzene and xylene (BTEX) (Danish EPA 2016). BTEX are therefore the sub-group of volatile organic compounds. They are common indoor contaminants emitted indoors during the 
combustion of firewood as primary air pollutants entering the atmosphere (Danish EPA 2016; Nielsen et al. 2008).

Evtyugina et al. (2013) characterised the emissions of volatile organic compounds from wood combustion in a fireplace and in a woodstove of two common species of trees and found Pyrenean oak species to emit higher emissions in the woodstove than in the fireplace, for the majority of detected compounds, and the opposite was observed for benzene and benzene-related compounds represent the most abundant group, followed by oxygenated VOCs and aliphatic. Cheng et al. (2017) assessed the concentrations of eight indoor volatile organic compounds (benzene, toluene, xylenes, butyl acetate, styrene, isopropylbenzene, undecane and formaldehyde) and found exposure doses of benzene and formaldehyde to exceed the benchmarks with toluene being the most predominant among all targeted compounds. Kitchens contain different chemical compounds, and exposures to specific chemicals, their toxicity and associated health risks are highly variable. Therefore, a priority ranking of chemicals and exposures, which causes concern, is difficult and uncertain (SCHER 2007). However, this study considers that BTEX are compounds of concern emitted from firewood during cooking in the kitchens because they have caused adverse health effects as indoor pollutants or have a high potential to cause health effects (Nielsen et al. 2008). Selected VOCs are discussed in Table 1.

Batterman et al. (2014) confirm that there are numerous potential sources of BTEX. Thus, exclusively associating BTEX exposure to firewood use can be seriously misleading, as ambient BTEX can also disperse and be found indoors such as in kitchens. These dispersed BTEX may also cause certain acute or chronic health conditions under certain concentration.

Furthermore, certain home products also contain BTEX. Thus, their frequent use may increase the probability of exposure and the emergence or prevalence of BTEX-related health conditions. In addition, people living in cities and industrial areas are generally exposed to higher levels of ambient BTEX than are those in rural areas (Rumchev et al. 2004). In residential buildings, domestic heating, cooking and smoking are also major sources of BTEX (Annesi-Maesano et al. 2013). For these reasons, it is important to note that firewood users who are also vulnerable or exposed to the above major BTEX sources, who may also be resident of cities or industrial areas, may be exposed to aggravated levels of BTEX. Ventilation differences between the different types of buildings were shown to be a major factor in varying concentrations of BTEX. For example, a study conducted by Crump et al. (2005) found that houses where windows were open most or all the time had significantly (probability of $\geq 95 \%$ ) higher ventilation rates than other houses. The installation of smoke controls (e.g. chimneys), ventilation to dilute contaminants and filtration is believed to improve indoor air quality in households; however, most do not have these controls $(\mathrm{Wu}$ et al. 2017). Smith and Akbar (2003) argue that chimneys tend to shift the environmental problem from the household level to the community and global levels. Community-level pollution re-enters households, thereby recreating household-level pollution, defeating the aim of interventions aimed at improving air quality. Interventions in the form of cook stoves aimed at lowering indoor emissions have also failed (Clark et al. 2010; Huboyo 2015). Levels of indoor air pollution are, in some cases, higher than the set standards or than the international standards set by the WHO. Zidago and Wang (2016) believe dependency on firewood fuel will only improve if governments intervene with innovative plans and policies. House characteristics may greatly influence concentrations of pollutants but are often overlooked as factors in indoor air pollution (Dasgupta et al. 2009; Le et al. 2014; Riojas-Rodriguez et al. 2001).

Risk assessments have been applied in different countries for the toxic pollutants as regulatory decision-making processes to combat air pollution. In a risk assessment, the extent to which a population is or may be exposed to a certain chemical is determined, and the extent of exposure is considered in relation to the kind and degree of hazard posed by the chemical, thereby permitting an estimate of the potential health risk due to that chemical for the population involved. This study adopted environmental health risk assessment to assess the extent to which kitchen structures influence exposure of households to BTEX emitted during cooking using firewood in Senwabarwana.

\section{Materials and methods}

The methods adopted in the current study build on previous publications by Semenya and Machete (2018, 2019a, b). In the later publications, surveys, observations and ethnobotanical meta-analysis were used to study the priority firewood plant species used by Bapedi households in Senwabarwana Villages, namely mushu, moretshe, mohwelere, mokgwa and motswiri. The current study therefore burnt $1 \mathrm{~kg}$ of each priority firewood species for experimentation and collected sample of each of the four selected VOCs (benzene, toluene, ethylbenzene and xylene) with the use of active sampling methods. Tedlar bags were used in a kitchen simulated laboratory room of $4.5 \mathrm{~m}^{2}$ floor area, $2.4 \mathrm{~m}$ floor to ceiling height. The bag was connected to a pump and air was sampled at a flow rate of $5 \mathrm{~mL} / \mathrm{min}$ for $1 \mathrm{~h}$, as recommended by SKC (2018a, b). It was estimated that cooking takes place for an hour (USEPA 1996). VOC monitoring over a 5-day period in spring (September 2018) was considered adequate since assessment considered acute rather than chronic exposure (USEPA 1996). The VOC bags were analysed at an accredited laboratory (SKC South Africa Chemtech Laboratory, accreditation number T0361) using the NIOSH 2549 analytical method. 


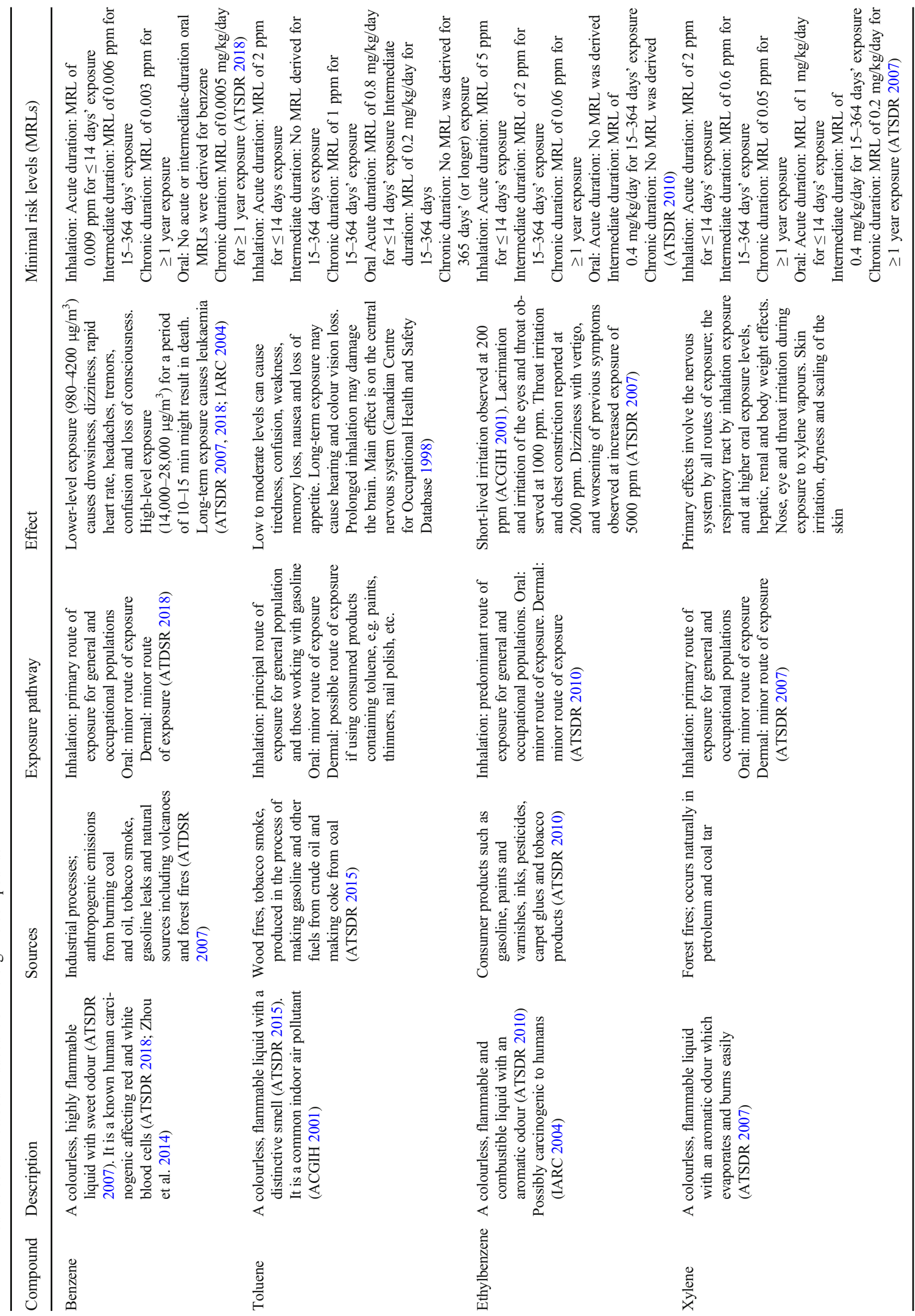


The results of the experiment (VOCs) were descriptively and statistically analysed and presented through frequency tables and figures. Correlational statistical analysis was also used to determine the influence of kitchen structural characteristics on households' exposure to VOCs. Data on the kitchen structural characteristics, as variables of this study, were collected through observations and survey. This data was also descriptively and correlational statistically analysed and presented qualitatively and quantitatively. Ultimately, the results of the study were presented according to the adopted integrated environmental health risk assessment framework (Semenya and Machete 2019b). The IEHRA is a threestaged framework consisting of toxicity assessment, exposure assessment and risk characterisation.

\section{Results and discussion}

The IEHRA framework has been adopted in the presentation format of the current study results as adopted from Machete (2017). Consequently, the results are presented according to the three IEHRA stages, namely toxicity assessment, exposure assessment and rich characterisation:

\section{Toxicity assessment}

The toxicity assessment revealed that BTEX are pollutants released during the burning of firewood. No other potential presence of sources of BTEX such as paints, detergents, upholstery fabrics, furniture wax, adhesives, varnishes, glues, carpets, vinyl floors, cleaning chemicals, air fresheners and cosmetics were found in the kitchens. All the respondents used firewood in open-fire three-stone stoves for cooking, and this practice has the potential to cause adverse health effects through the inhalation of smoke released from combustion. Through experimentation, toxicological assessment revealed that there are several pollutants released during combustion of firewood species. It was revealed that VOCs such as benzene, toluene, ethylbenzene and xylene are released as pollutants from the combustion of the firewood used as fuel in Senwabarwana.
Table 2 presents the detected concentrations of BTEX during the burning of the wood of each tree species. These are the concentrations that the community of Senwabarwana is exposed to during the indoor burning of firewood.

The lowest benzene concentration was detected in motswiri, mokgwa and mohwelere. A high concentration of toluene was emitted by the burning of mushu, followed by moretshe, while low concentrations were obtained from burning motswiri, mokgwa and mohwelere. Ethylbenzene and xylene were emitted from the burning of mushu only and were not detected in the other firewood species. Higher concentrations could be expected during prolonged continuous monitoring as well as in the winter months, when the area becomes prone to pollution accumulation due to climatic conditions.

Few jurisdictions have developed indoor air guidelines. No indoor air guidelines were found for BTEX components in South Africa, and so, relevant guidelines from anywhere in the world could be used; for the purposes of the study, the acute reference exposure level (REL) from California was adopted (OEHHA 2019). Average exposure time for acute RELs is $1 \mathrm{~h}$. REL assumes that toxic effects will not occur until a threshold dose is exceeded (NRC 1994).

According to the World Health Organization (2010), there is no safe level of exposure to benzene. Even though the REL from California was used in the study, it is assumed that benzene has a negative health effect at all levels of exposure. Only mushu exceeded the acute benzene REL from California, while motswiri, moretshe, mokgwa and mohwelere did not exceed the given REL. No toluene was detected because of the burning of mokgwa and mohwelere, while the burning of motswiri, moretshe and mushu yielded concentrations lower than the recommended REL of toluene. No ethylbenzene or xylene was detected associated with the use of motswiri, mokgwa or mohwelere. A lower ethylbenzene concentration than the REL was associated with the use of moretshe, while ethylbenzene associated with the use of mushu exceeded the REL value. Xylene levels lower than the REL value were associated with the use of both mushu and moretshe.

Table 2 Detected levels of VOC concentration per selected tree species $\left(\mu \mathrm{g} / \mathrm{m}^{3}\right)$

\begin{tabular}{|c|c|c|c|c|c|c|}
\hline \multirow[t]{2}{*}{ Chemicals } & \multicolumn{5}{|c|}{ Detected concentration of BTEX per plant species $\left(\mu \mathrm{g} / \mathrm{m}^{3}\right)$} & \multirow{2}{*}{$\begin{array}{l}\text { Inhalation acute reference exposure } \\
\text { level }\left(\mu \mathrm{g} / \mathrm{m}^{3}\right)(\text { OEHHA 2019) }\end{array}$} \\
\hline & Mushu & Moretshe & Motswiri & Mokgwa & Mohwelere & \\
\hline Benzene & 41.0 & 13.3 & 0.01 & 0.01 & 0.01 & 27 \\
\hline Toluene & 22.7 & 8.7 & 0.01 & Not detected & Not detected & 37 \\
\hline Ethylbenzene & 2.2 & 0.01 & Not detected & Not detected & Not detected & 2 \\
\hline Xylene & 0.01 & 0.01 & Not detected & Not detected & Not detected & 22,000 \\
\hline
\end{tabular}




\section{Exposure assessment}

The pollutants listed above can cause various health effects once exposure has occurred. Such health effects vary, depending on the length of time for which an individual has been exposed and the concentrations s/he was subjected to. The respondents in Senwabarwana indicated that they cook once and/or twice a day (morning and/or evening). It is assumed that cooking takes approximately $1 \mathrm{~h}$ (USEPA 1996). The kitchens are used mainly for cooking and body warming in winter. It was therefore necessary to assess the kitchen structures as they may influence exposure to firewood smoke during cooking. The characteristics of the kitchens are given in Table 3. Seven per cent of respondents had no kitchens and cooked in the open spaces outside their homes. Although this might reduce personal exposure to pollutants, it affects the environment. Twenty per cent of the homes were made of mud and had thatch roofs, while $73 \%$ of the kitchens were made of cement and had corrugated iron sheet roofs.

Dasgupta et al. (2009) studied the effect of building materials on indoor air pollution and found corrugated zinc to contribute the most to healthy air quality, followed by thatch, mud and brick. No chimneys were observed in any of the houses. The kitchens had doors (93\%), while 7\% had no windows. In some homes (17\%), there were small openings in the walls, instead of windows. Some kitchens had two windows (65\%)

Table 3 kitchen structural characteristics $(N=69)$

\begin{tabular}{lll}
\hline Kitchen elements or factors & Number & Percentage \\
\hline Number of households with kitchens & 64 & 93 \\
Number of households without kitchens & 5 & 7 \\
Types and shapes of the kitchens & & \\
Rondavel & 14 & 20 \\
Square house & 50 & 73 \\
Roof type (n=64) & & \\
Corrugated iron sheet & 50 & 73 \\
Kitchens without roofs & 5 & 7 \\
Thatch roof & 14 & 20 \\
Kitchen wall materials & & \\
Mud & 14 & 20 \\
Cement & 51 & 74 \\
Corrugated iron sheet & 4 & 6 \\
Number of windows per kitchen & & \\
No windows & 12 & 17 \\
One window & 12 & 17 \\
Two windows & 45 & 65 \\
Number of kitchen doors & 54 & 93 \\
Kitchens without doors & & \\
One door & 59 & \\
\hline
\end{tabular}

while others had only one window (17\%). The national building regulation of South Africa requires the minimum ventilation of a room to be $5 \%$ of its floor area. However, none of the kitchens in the study area complied with this requirement due to poor house design. The structural design of kitchens in the study area is characterised by a limited number of windows, the size of which is usually small, thereby limiting the exchange of indoor air with outdoor air.

It was observed that respondents opened windows and doors when cooking to allow ventilation. However, pollutants cannot disperse properly due to poor kitchen structures putting residents at risk (Mukkannawar et al. 2014).

\section{Reported health effects}

Short-term exposure to high levels of BTEX can cause acute symptoms such as headache, eye, nose and throat irritation, dizziness, nausea and vomiting and the exacerbation of asthma symptoms (Danish EPA 2016; Pokhrel et al. 2010; Nielsen et al. 2008; Han and Naeher 2006). Long-term exposure to high levels of VOCs can increase the risk of liver damage, kidney damage, cancer and central nervous system damage (ATSDR 2007; IARC 2004).

Figure 1 presents common health effects associated with the use of firewood reported in Senwabarwana.

Majority (46\%) of the respondents indicated to have experienced headache when exposed to firewood smoke. Thirtythree percent (33\%) of the respondents experienced eye problems which includes sore, red and teary eyes. Relying of selfreported sickness may render the results of the study unreliable; however, literature confirms that exposure to VOCs can irritate the eyes since VOCs are irritants to the eyes and respiratory tract (Pokhrel et al. 2010; IARC 2004). These results are also supported by the results of a case-control study of indoor cooking smoke exposure and cataract prevalence in Nepal and India which found that the use of solid fuel in unfuelled indoor stoves is associated with an increased risk of eye problems (Pokhrel et al. 2005). Twelve per cent of respondents self-reported asthma while 3\% self-reported incidents of cancer. Only $1 \%$ of the respondents reported pneumonia while $9 \%$ reported heart problems and $4 \%$ reported incidents of stroke. These results are used to confirm the presence of VOCs in the firewood smoke as indicated in Table 2.

\section{Link between health effects and kitchen characteristics}

Figure 2 presents the relationship between health effects and kitchen structures. This is a test of statistical significance to compare the frequency of reported health effects by the absence or presence of chimneys, doors and windows, by roof and wall material. It is observed that respondents whose homes had no roof reported fewer health effects, followed 


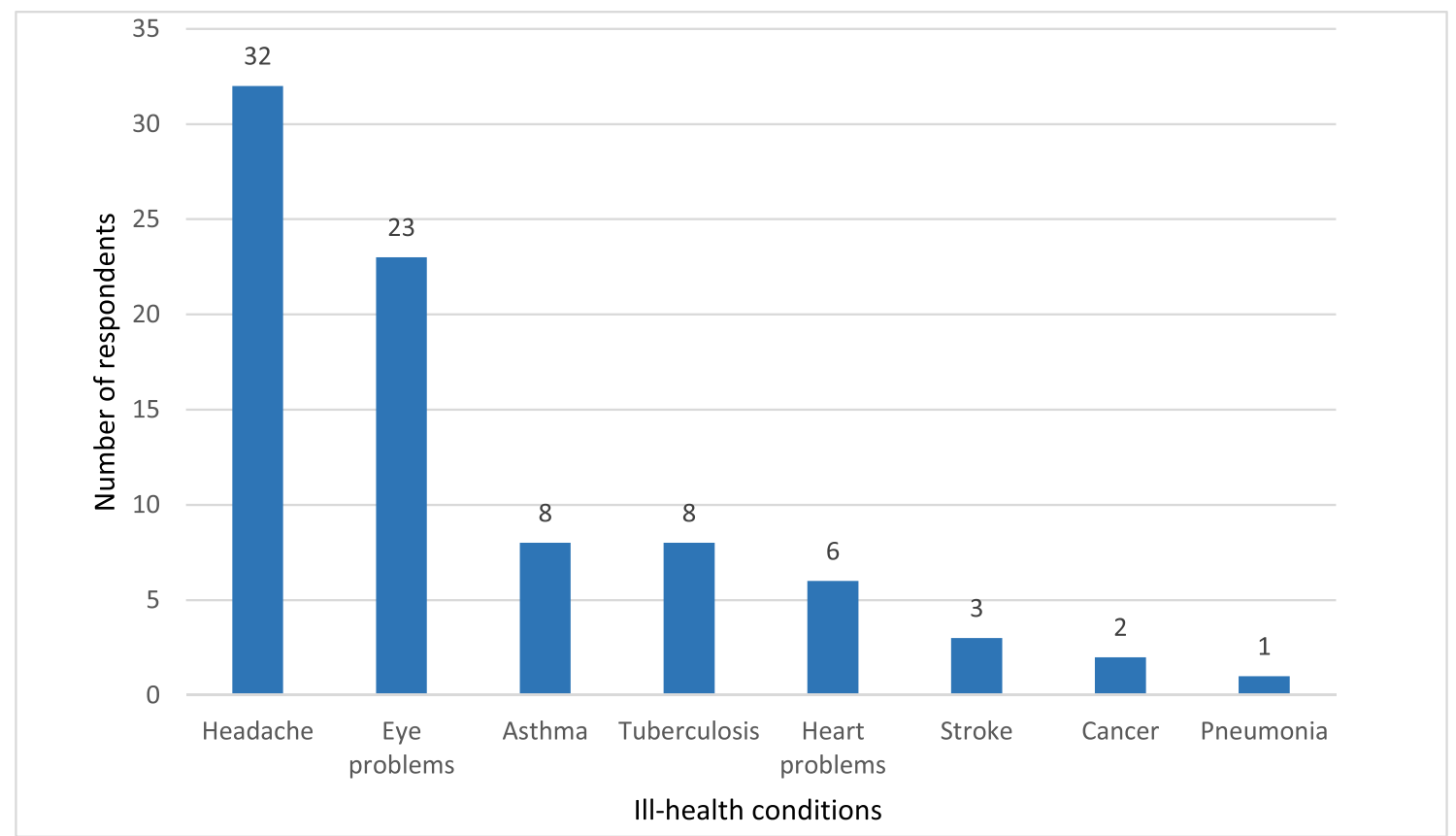

Fig. 1 Ill health conditions reported by households $(N=69)$

by those whose roof is made of thatch while those with corrugated roofs reported the highest health effects.

All the respondents had no chimneys and therefore reported the highest health effects. Those whose kitchens are made of cement reported the highest health effects compared to those whose kitchens are made of mud walls followed by those whose kitchen walls are made of corrugated zinc sheets.
Those whose kitchens had windows reported higher health effects compared to those who use kitchens without windows. This might be due to the fact those without windows mostly has no roof while those with windows are not built according to the national standard making it difficult for outdoor air to dilute the indoor air thereby increasing pollutant level inside the kitchen (Mukkannawar et al. 2014).

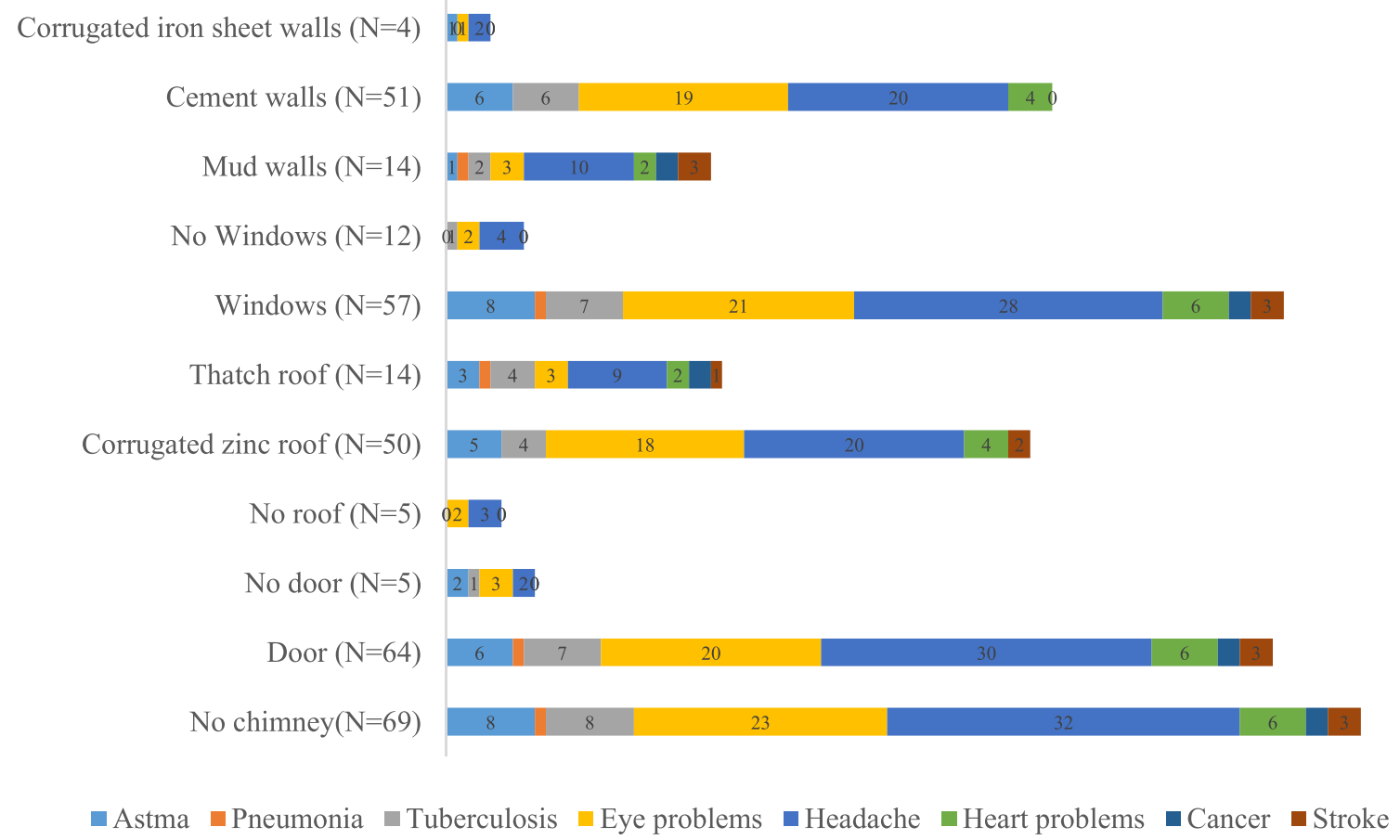

Fig. 2 The link between health effects and kitchen characteristics 


\section{Risk assessment}

This step combines the information from the two previous steps to provide an indication of the nature and expected frequency of adverse health effects in exposed populations. The fundamental assumption of the sampling strategy consists of the fact that measured concentrations represent maximum concentrations to which all individuals could be exposed in the kitchen (USEPA 2014). If this assumption is true, then the risk of developing health effects due to the presence of the studied volatile organic compounds can be assessed as negligible. This holds for all BTEX (concentrations remain below the risk levels). Benzene poses a health risk in households where mush $u$ and moretshe are used. There is, however, no health risk associated with the use of mokgwa, mohwelere and motswiri. Similarly, toluene poses a health risk when mushu and moretshe are used, while there is no health risk associated with the use of mokgwa, mohwelere and motswiri. Ethylbenzene poses a health risk when mushu is used as firewood. Xylene has no health risk associated with the use of all five-tree species.

The type of kitchen structures coupled with the use of firewood however seems to affect indoor air quality and householders' health. Even though the pollutant's level is lower than the guideline values, it should be noted that these householders are exposed to pollutants every day.

A limitation of the study is that it was conducted for a limited period; therefore, the estimation of risks over longer periods of exposure could not be assessed.

\section{Conclusion}

This paper assessed the influence of kitchen structures on emissions of selected VOCs (BTEX) by different firewood species used in Senwabarwana. The health effects of emitted BTEX were also assessed. Rudimentary stoves without chimneys are used for cooking, exposing respondents to emissions. It was found that the kitchens in the study area were made of different materials such as corrugated iron, mud and cement. Kitchen ventilation was also assessed, and it was found that most kitchens are located outside the main house and are used mainly for cooking purposes. To increase ventilation, residents opened doors and windows during the cooking process, thus reducing the risk of adverse health effects.

Mushu was found to emit the highest concentrations of BTEX. Ethylbenzene and xylene were not detected in motswiri, mohwelere and mokgwa, while benzene and toluene were detected below the detection limit. The study found the VOC concentration to be below the WHO standards for those cooking with firewood. Each of the VOCs derived from firewood combustion has certain health effects on the human body. However, lower limits were detected in this study, suggesting that the community of Senwabarwana-which relies on firewood - is at lower risk of the ill effects associated with burning firewood. The risk assessment of health effects reported in Senwabarwana leads to the conclusion that reported health complaints are not due to the presence of the measured compounds.

Open Access This article is licensed under a Creative Commons Attribution 4.0 International License, which permits use, sharing, adaptation, distribution and reproduction in any medium or format, as long as you give appropriate credit to the original author(s) and the source, provide a link to the Creative Commons licence, and indicate if changes were made. The images or other third party material in this article are included in the article's Creative Commons licence, unless indicated otherwise in a credit line to the material. If material is not included in the article's Creative Commons licence and your intended use is not permitted by statutory regulation or exceeds the permitted use, you will need to obtain permission directly from the copyright holder. To view a copy of this licence, visit http://creativecommons.org/licenses/by/4.0/.

\section{References}

Agency for Toxic Substance and Disease Registry (2007) The toxic guide. Retrieved from https://www.atsdr.cdc.gov/substances/ toxsubstance.asp?toxid=14 3 Oct 2018

Agency for Toxic Substance and Disease Registry (2010) Toxicological profile for ethylbenzene. Retrieved from https://www.atsdr.cdc.gov/ substances/toxsubstance.asp?toxid=14 5 Oct 2018

Agency for Toxic Substance and Disease Registry (2015) Toxicological profile for toluene. Retrieved from https://www.atsdr.cdc.gov/ substances/toxsubstance.asp?toxid=14 5 Oct 2018

Agency for Toxic Substance and Disease Registry (2018) Minimal risk levels. Accessed from https://www.atsdr.cdc.gov/mrls/pdfs/atsdr mrls.pdf on 5 Oct 2018

American Conference of Government Industrial Hygienists (2001) Guide to occupational exposure values. Retrieved from https://www.acgih. org/forms/store/ProductFormPublic/guide-to-occupationalexposure-values-2001. Accessed 30 Jan 2018

Annesi-Maesano I, Baiz N, Banerjee S, Rudani P, Rive S, on behalf of the SINOPHONIE group (2013) Indoor air quality and sources in schools and related health effects. J Toxicol Environ Health 16(8): $491-550$

Balakrishnan K, Mehta S, Kumar P, Ramaswamy P, Sambandam S, Kumar KS, Smith KR (2004) Indoor air pollution associated with household fuel use in India: an exposure assessment and modelling exercise in rural districts of Andhra Pradesh, India. The World Bank and ESMAP, India

Batterman S, Su F-C, Li S, Mukherjee B, Jia C (2014) Personal exposure to mixtures of volatile organic compounds: modeling and further analysis of the RIOPA date. Research report 181. MA Health Effects Institute, Boston

Bruce N, Perez-Padilla R, Albalak R (2000) Indoor air pollution in developing countries: a major environmental and public health challenge. Bull World Health Organ 78(2000):1078-1092

Canadian Centre for Occupational Health and Safety (1998) Database. Retrieved from http://ccinfowed.ccohs.ca 3 Oct 2018

Caravanos J, Kevin C, Bret E, Landrigan PJ, Fuller R (2013) The burden of disease from pediatric lead exposure at hazardous waste sites. Environ Res 120(2013):119-125 
Cattaneo A, Taronna M, Garramone G, Peruzzo C, Schlitt C, Consonni D, Cavallo DM (2010) Comparison between personal and individual exposure to urban air pollutants. Aerosol Sci Technol 44(5):370 379

Chakraborty D, Mondal NK, Datta JD (2014) Indoor pollution from solid biomass fuel and rural health damage: a micro-environmental study in rural area of Burdwan, West Bengal. Sustain Built Environ 3(2014):262-271

Cheng Z, Li B, Yu W, Wang H, Zhang T, Bu Z (2017) Risk assessment of inhalation exposure to VOCs in dwellings in Chongqing, China. Healthy buildings 2017, Europe ISBN: 978-83-7947-232-1

Clark LM, Reynolds SJ, Burch JB, Conway S, Bachand AM, Peel JL (2010) Indoor air pollution, cookstove quality, and housing characteristics in two Honduran communities. Environ Res 110:12-18

Crump D, Dimitroulopoulou S, Squire R, Ross D, Pierce B, White M, Brown V, Coward S (2005) Ventilation and indoor air quality in new homes. Pollut Atmos. Accessible: https://www.researchgate. net/publication/310952768 and https://www.umad.de/infos/ cleanair13/pdf/full 104.pdf

Danish Environmental Protection Agency (EPA) (2016) Survey and risk assessment of toluene and other neurotoxic substances in children's rooms. Retrieved from https://www2.mst.dk/Udgiv/publications/ 2016/02/978-87-93435-42-1.pdf 17 Mar 2018

Dasgupta S, Wheeler D, Huq M, Khaliquzzaman M (2009) Improving indoor air quality for poor families: a controlled experiment in Bangladesh. Indoor Air 19(1):22-32

Department of Health (2018) Guideline for the management of indoor air quality: a guide for environmental health practitioners in South Africa. South Africa, Pretoria

Duflo E, Greenstone M, Hanna R (2008) Indoor air pollution, health and economic wellbeing. Surv Perspect Integr Environ Soc 1(1):7-16

Evtyugina M, Alves CA, Calvo T, Nunes L, Tarelho M, Duarte, Prozil SO (2013) Emission of volatile organic compounds from the residential combustion of Pyrenean oak and black poplar. Int J Environ Ecol Eng 7(6)

Gawryś M, Fastyn P, Gawłowski J, Gierczak T, Niedzielski J (2001) Prevention of water vapour adsorption by carbon molecular sieves in sampling humid gases. J Chromatogr A 933(1-2):107-116

Government Gazette (2012) Air quality act- South African government. Retrieved from https://www.gov.za/sites/www.gov.za/files/35072 144_g.pdf 01 Oct 2018

Guide to occupational exposure values (n.d.) Retrieved from https:// www.acgih.org/forms/store/ProductFormPublic/guide-tooccupational-exposure-values-2001 30 Jan 2018

Guo H, Lee SC, Chan LY, Li WM (2003) Risk assessment of exposure to volatile organic compounds in different indoor environments. Environ Res 94:57-66

Habeebullah T (2012) Risk assessment of exposure to volatile organic compounds in the holy city of Makkah. Environ Impact 162:625635

Han X, Naeher LP (2006) A review of traffic-related air pollution exposure assessment studies in the developing world. Environ Int 32(1): $106-120$

Huboyo HS (2015) Household characteristics and potential indoor air pollution issues in rural Indonesian communities using fuelwood energy. J Ilmu Lingkungan 13(1):27-35

Hubuyo S, Tohno S, Lestari P, Mizohata A, Okumura M (2014) Characteristics of indoor air pollution in rural mountainous and rural coastal communities in Indonesia. Atmos Environ 82:343-350

Inkoom DKB, Crentsil AO (2015) Estimation of indoor air pollution and health impacts due to biomass burning in rural northern Ghana. In: GDEE (ed) Case studies for developing globally responsible engineers. Global dimension in engineering education, Barcelona Retrieved from http://gdee.eu/index.php/resources.html 18 Apr 2018
Innovative Occupational Hygiene Solutions (2018) Indoor air quality. Retrieved from http://www.iohsolutions.com/occupational-hygiene/indoor-air-quality 29 May 2018

International Agency for Research on Cancer (2004) Overall evaluation of carcinogenicity to humans. IARC monographs. Accessed from $\mathrm{http}: / /$ www.monographs.iarc.fr/ENG/Classification/latest_classif. php 27 Sept 2018

Janis S (2001) Landfill sites: risk of adverse birth outcomes. Pract Nurs 1: 66

Jones D (1992) Nomenclature for hazard and risk assessment in the process industries. Institution of Chemical Engineers, Rugby

Le A, Bearman G, Sanogo K, Stevens MP (2014) Perception and barriers to indoor air quality and perceived impact on respiratory health: an assessment in rural Honduras. Adv Public Health 2014:1-6. https:// doi.org/10.1155/2014/105260

Machete F (2017) Environmental health risks associated with e-waste exposure in Badplaas, Carolina and Elukwatini landfills, Republic of South Africa. Afr J Sci Technol Innov Dev 9:679-684. https:// doi.org/10.1080/20421338.2017.1355602

Mukkannawar U, Kumar R, Ojha A (2014) Indoor air quality in rural residential area-Pune case study. Int J Curr Microbiol App Sci 3(11): 683-694

National Research Council (1994) Science and judgement in risk assessment. National Academy Press, USA

Nielsen E, Dybdahl M, Larsen PB (2008) Health effects assessment of exposure to particles from wood smoke. Danish Ministry of the Environment: Environmental Protection Agency. Retrieved from http://www.orbit.dtu.dk/.../Health_effects_assessment_of exposure_to_particles_from_woodsmoke. Accessed 19 May 2018

OEHHA (California Office of Environmental Health Hazard Assessment) (2019) Acute, 8-hour and chronic reference exposure level (REL) summary uploaded 4 November 2019. Retrieved from http://oehha.ca.gov/general info 20 Dec 2019

Olave RJ, Forbes EGA, Johnson CR, Relf J (2017) Particulate and gaseous emissions from different wood fuels during combustion in a small-scale biomass heating system. Atmos Environ 157:49-58

Oosthuizen MA, Wright CY, Matooane M, Phala N (2015) Human health risk assessment of airborne metals to a potentially exposed community: a screening exercise. Clean Air J 25(1):51-57

Pokhrel AK, Smith KR, Khalakdina A, Deuja A, Bates MN (2005) Casecontrol study of indoor cooking smoke exposure and cataract in Nepal and India. Int J Epidemiol 34:702-708

Pokhrel AK, Bates MN, Verma SC, Joshi HS, Sreeramareddy CT, Smith KR (2010) Tuberculosis and indoor biomass and kerosene use in Nepal: a case-control study. Environ Health Perspect 118(4):554 468

Riojas-Rodriguez H, Romano-Riquer P, Santos-Burgoa C, Smith KR (2001) Household firewood use and the health of children and women of Indian communities in Chiapas, Mexico. Int J Occup Environ Health 7(1):44-53

Rumchev K, Spickett J, Bulsara M, Phillips M, Stick S (2004) Association of domestic exposure to volatile organic compounds with asthma in young children. Thorax 59:746-751. https://oi. org/10.1136/thx.2003.013680

Rumchev K, Brown H, Spickett J (2007) Volatile organic compounds: do they present a risk to our health? Rev Environ Health 22(1):39-55

Scientific Committee on Health and Environmental Risks (SCHER) (2007) Opinion on risk assessment on indoor air quality. Scientific committees Access from http://eceuropaeu/health/ph_risk/ risk_en.htm 10 Oct 2018

Semenya K, Machete F (2018) African indigenous criteria, which Bapedi households in Senwabarwana village use for selecting domestic firewood. Conference proceedings: First International Conference on Sustainable Management of Natural Resources (ICSMNR2018). Bolivia Lodge Polokwane, South Africa, 15th - 
17th October 2018. Reference: ICSMNR08009. ISBN: 978-0-62082267-1

Semenya K, Machete F (2019a) Factors associated with firewood preferences among electrified Bapedi households of Senwabarwana villages, South Africa. Afr J Sci Technol Innov Dev 11:719-729. https://doi.org/10.1080/20421338.2019.1572336

Semenya K, Machete F (2019b) Integrated environmental health risk assessment framework for firewood-induced indoor air pollution. WIT Trans Ecol Environ 236:179-190. https://doi.org/10.2495/ AIR190181

SKC (2018a) Step by step guide (an introduction to air sampling) Retrieved from http://www.skcltd.com 10 Nov 2017

SKC (2018b) Application guide (sampling train- air sample bags) Retrieved from http://www.skcltd.com 10 Nov 2017

Smith KR, Akbar S (2003) Health damaging air pollution: a matter of scale. In: McGranaham G, Murray F (eds) Air pollution and health in rapidly developing countries. Earthscan Publications Ltd, United Kingdom

United States Environmental Protection Agency (1996) Exposure Factors Handbook: Draft. Update to EPA/600/8-89/043 - May 1989. Retrieved from http://www.epa.gov/oar/oagps/regusmog/infpart. html. Accessed 26 Sept 2018

United States Environmental Protection Agency (2014) Framework for Human Health Risk Assessment to Inform Decision Making. Retrieved from https://www.epa.gov/sites/production/files/201412/.../hhra-framework-final-2014.pdf 26 Sept 2018
United States Environmental Protection Agency (2018) Indoor air quality. Technical overview of Volatile Organic Compounds. Retrieved from: https://www.epa.gov/indoor-air-quality-iaq/technicaloverview-volatile-organic-compounds 26 Sept 2018

Update to EPA/600/8-89/043 1989. Retrieved from http://www.epa.gov/ oar/oagps/regusmog/infpart.html 26 Sept 2018

World Health Organisation (2010) WHO guidelines for indoor air quality: selected pollutants. Retrieved from: www.euro.who.int/en/.../ who-guidelines-for-indoor-air-quality-selected-pollutants 10 Nov 2018

World Health Organisation (WHO) (2018) Household air pollution: fact sheet. Retrieved from http://www.who.int/en/news-room/factsheets/detail/household-air-pollution-and-health 10 May 2018

Wu W, Zhu H, Qu Y, Xu K (2017) Regional disparities in emissions of rural household energy consumption: a case study of Northwest China. Sustainability 9(76):1-17

Zhou Y, Zhang S, Li Z, Zhu J, Bi Y, Bai Y, Wang H (2014) Maternal benzene exposure during pregnancy and risk of childhood acute lymphoblastic leukemia: a meta-analysis of epidemiologic studies. PLoS One 9(10)

Zidago AP, Wang Z (2016) Charcoal and fuelwood consumption and its impacts on the environment in Cote d'Ivoire (case study of Yopougon area). Can Center Sci Educ 6(4):26-35

Publisher's note Springer Nature remains neutral with regard to jurisdictional claims in published maps and institutional affiliations. 